Communication

\title{
Carbonaceous Adsorbent Derived from Sulfur-Impregnated Heavy Oil Ash and Its Lead Removal Ability from Aqueous Solution
}

\author{
Takaaki Wajima \\ Department of Urban Environment Systems, Graduate School of Engineering, Chiba University, 1-33 Yayoi-cho, \\ Inage-ku, Chiba 263-8522, Japan; wajima@tu.chiba-u.ac.jp; Tel.: +81-43-290-3507
}

Received: 14 September 2020; Accepted: 17 November 2020; Published: 18 November 2020

\begin{abstract}
A novel carbonaceous adsorbent was prepared from sulfur-impregnated heavy oil ash via pyrolysis using potassium sulfide $\left(\mathrm{K}_{2} \mathrm{~S}\right)$ solution, and its ability to remove lead $\left(\mathrm{Pb}^{2+}\right)$ from aqueous solutions was examined. It was compared with an adsorbent synthesized by conventional pyrolysis using potassium hydroxide $(\mathrm{KOH})$ solution. Specifically, the raw ash was immersed in $1 \mathrm{M} \mathrm{K}_{2} \mathrm{~S}$ solution or $1 \mathrm{M} \mathrm{KOH}$ solution for 1 day and subsequently heated at $100-1000{ }^{\circ} \mathrm{C}$ in a nitrogen $\left(\mathrm{N}_{2}\right)$ atmosphere. After heating for $1 \mathrm{~h}$, the solid was naturally cooled in $\mathrm{N}_{2}$ atmosphere, and subsequently washed and dried to yield the product. Regardless of the pyrolysis temperature, the product generated using $\mathrm{K}_{2} \mathrm{~S}$ (Product- $\mathrm{K}_{2} \mathrm{~S}$ ) has a higher sulfur content than that obtained using $\mathrm{KOH}$ (Product-KOH). Moreover, Product- $\mathrm{K}_{2} \mathrm{~S}$ has a higher lead removal ability than Product- $\mathrm{KOH}$, whereas the specific surface area of the former is smaller than that of the latter. Product- $\mathrm{K}_{2} \mathrm{~S}$ obtained at $300{ }^{\circ} \mathrm{C}$ (Product- $\mathrm{K}_{2} \mathrm{~S}-300$ ) achieves the highest lead adsorption and a high selective lead removal from a ternary $\mathrm{Pb}^{2+}-\mathrm{Cu}^{2+}-\mathrm{Zn}^{2+}$ solution. The equilibrium capacity of Product- $\mathrm{K}_{2} \mathrm{~S}-300$ was found to fit the Langmuir model better than the Freundlich model, and its calculated maximum adsorption capacity is $0.54 \mathrm{mmol} / \mathrm{g}$. From the ternary $\mathrm{Pb}^{2+}-\mathrm{Cu}^{2+}-\mathrm{Zn}^{2+}$ solution, the order of adsorption by Product- $\mathrm{K}_{2} \mathrm{~S}-300$ is $\mathrm{Pb}^{2+}>\mathrm{Cu}^{2+}>\mathrm{Zn}^{2+}$, and the removal of $\mathrm{Pb}^{2+}$ and $\mathrm{Cu}^{2+}$ increases as the $\mathrm{pH}$ of the solution increases.
\end{abstract}

Keywords: heavy oil ash; $\mathrm{K}_{2} \mathrm{~S}$ immerse; pyrolysis; lead removal; selectivity

\section{Introduction}

In oil-fired power plants, oil-fired fly ash following discharge, prior to passing through a flue, is collected by cyclones or electrostatic precipitators. The ash is mainly composed of unburned carbon (up to $90 \mathrm{wt. \% ),} \mathrm{water-soluble} \mathrm{sulphates,} \mathrm{and} \mathrm{metal} \mathrm{oxides,} \mathrm{such} \mathrm{as} \mathrm{iron} \mathrm{(1-5} \mathrm{wt. \% ),} \mathrm{vanadium} \mathrm{(0.6-3.6} \mathrm{wt. \% ),}$ and nickel (0.1-1.7 wt.\%) oxides. There is concern regarding the environmental problems of ash, such as generation of acidic liquid, release of heavy metals, and dusting. Because oil-fired fly ashes have a high content of vanadium $(\mathrm{V})$ and nickel $(\mathrm{Ni})$, their recovery from heavy oil ash has attracted attention since the 1960s worldwide [1]. In the traditional hydrometallurgical processes [2], in the first leaching stage, the vanadium and nickel compounds in ash are dissolved in acidic or basic solutions. Consequently, the produced unburned carbon (carbonaceous residues) from the ash has to be disposed of to landfill sites, requiring high processing costs [3]. Because they have a high carbon content and heavy metal-free, these residues can be used as precursors for activated carbon [4-6] or be burned with or without coal in a coal boiler for energy recovery.

Activated carbon has various uses in wastewater treatment for drinking water production, control of atmospheric pollution, and removal of poisonous gases. Activated carbon is favorable for removing organic chemicals from wastewater, whereas it is not promising for removing inorganic 
pollutants from aqueous solutions, because of its relatively nonpolar character [7]. This property prevents the attraction between some functional groups on activated carbon surface and charged metal species. The adsorption can be enhanced by introducing functional groups with high affinity for specific substrates by functionalization processes. The choice of functional groups allows defining the specificity of an adsorbing material for a particular substrate. For example, a bio-based substance (BBS) from composited bio-wastes was impregnated in $\gamma$-alumina to promote the adsorption of polar pollutants via the several acidic and basic functional groups of the BBS [8,9]. Activated carbon is typically modified by various ligands, which introduce additional heteroatoms so that the sorbent develops a high selectivity toward certain metal ions. Sulfur (S)-containing ligands prove more selective toward some heavy metals than their oxygen and nitrogen analogues [10-12]. In previous studies, S-impregnated carbonaceous adsorbents with high heavy metal removal were prepared from an industrial waste - paper sludge- by pyrolysis after immersion in potassium sulfide $\left(\mathrm{K}_{2} \mathrm{~S}\right)$ solution [13]. In the Pearson theory, a soft base, $\mathrm{S}$, had better to interact with soft acids, $\mathrm{Zn}^{2+}, \mathrm{Pb}^{2+}$, and $\mathrm{Cd}^{2+}$, instead of with a hard base, oxygen, in activated carbon [14,15]. Therefore, there is a possibility to manufacture a low-cost adsorbent with removal of heavy metals from carbonaceous heavy oil ash by pyrolysis with $\mathrm{K}_{2} \mathrm{~S}$ solution.

In this study, the preparation of a carbonaceous adsorbent with removal property of heavy metals from heavy oil ash by pyrolysis with $\mathrm{K}_{2} \mathrm{~S}$ solution was investigated, and the lead removal ability of the S-impregnated adsorbents was examined. This was motivated by $\mathrm{Pb}^{2+}$ being one of the representative poisons among heavy metals. In addition, to clarify the effect of $S$ in the raw ash, the adsorbent was prepared by the same procedure using potassium hydroxide $(\mathrm{KOH})$ solution to compare the properties of lead removal.

\section{Materials and Methods}

\subsection{Heavy Oil Ash}

A heavy oil ash collected from an electrostatic precipitator of a Japanese electric power plant in Akita was used. Table 1 lists some of the properties of this heavy oil ash. The proximate and ultimate analysis of the heavy oil ash is reported in Table 1. The raw ash has a high carbonaceous fraction content $(75-80 \%)$, appropriate for the preparation of a carbonaceous adsorbent.

Table 1. Analyses of raw ash.

\begin{tabular}{|c|c|}
\hline & Raw Ash \\
\hline \multicolumn{2}{|l|}{ Proximate analysis (wt $\%$ dry basis) } \\
\hline Volatile matter ${ }^{1}$ & 19.0 \\
\hline Fixed carbon & 73.3 \\
\hline Ash & 7.7 \\
\hline \multicolumn{2}{|l|}{ Ultimate analysis ( $w t \%$ dry ash free) } \\
\hline Carbon & 79.5 \\
\hline Hydrogen & 1.2 \\
\hline Nitrogen & 4.4 \\
\hline Sulfur & 4.0 \\
\hline \multicolumn{2}{|l|}{ Ash composition (wt $\%)$} \\
\hline $\mathrm{NiO}$ & 29.9 \\
\hline $\mathrm{Fe}_{2} \mathrm{O}_{3}$ & 18.8 \\
\hline $\mathrm{SO}_{3}$ & 14.1 \\
\hline $\mathrm{SiO}_{2}$ & 7.7 \\
\hline $\mathrm{CaO}$ & 6.2 \\
\hline $\mathrm{V}_{2} \mathrm{O}_{5}$ & 5.6 \\
\hline $\mathrm{Na}_{2} \mathrm{O}$ & 5.0 \\
\hline $\mathrm{Al}_{2} \mathrm{O}_{3}$ & 3.8 \\
\hline $\mathrm{ZnO}$ & 3.2 \\
\hline $\mathrm{MgO}$ & 1.1 \\
\hline $\mathrm{K}_{2} \mathrm{O}$ & 0.9 \\
\hline Specific surface area $\left(\mathrm{m}^{2} / \mathrm{g}\right)$ & 6.2 \\
\hline
\end{tabular}

${ }^{1}$ Value at $800{ }^{\circ} \mathrm{C}$. 


\subsection{Preparation of Adsorbent}

The preparation procedure for the adsorbent is shown in Figure 1. The raw ash $(10 \mathrm{~g})$ was added to $1 \mathrm{M} \mathrm{K}_{2} \mathrm{~S}$ solution or $1 \mathrm{M} \mathrm{KOH}$ solution $(100 \mathrm{~mL})$, stirred for 1 day, and then filtrated and dried in an oven to obtain $\mathrm{K}_{2} \mathrm{~S}$-immersed ash (Ash- $\mathrm{K}_{2} \mathrm{~S}$ ) or $\mathrm{KOH}$-immersed ash (Ash- $\left.\mathrm{KOH}\right)$, respectively. These immersed ashes were pyrolyzed, then washed with distilled water, and dried in an oven to prepare the carbonized products (Product- $\mathrm{K}_{2} \mathrm{~S}$ from Ash- $\mathrm{K}_{2} \mathrm{~S}$ and Product-KOH from Ash-KOH).

The pyrolysis was performed using a horizontal reactor, similar to a previous study [13]. Ash- $\mathrm{K}_{2} \mathrm{~S}$ or Ash-KOH was set in the middle of a quartz tube $\left(0.45 \mathrm{~mm}\right.$ inside diameter and $1 \mathrm{~m}$ length). $\mathrm{N}_{2}$ gas was injected to purge the air in the tube $\left(1.0 \mathrm{~L} / \mathrm{min}\right.$ rate) for $30 \mathrm{~min}$. The ashes were heated at $100-1000{ }^{\circ} \mathrm{C}$ in an electric furnace, with a $\mathrm{N}_{2}$ gas continuous flow $(1.0 \mathrm{~L} / \mathrm{min})$. After $1 \mathrm{~h}$ of heating, the product was naturally cooled under the flow of $\mathrm{N}_{2}$ gas in the tube $(1.0 \mathrm{~L} / \mathrm{min}$ rate), and finally, it was collected from the tube.

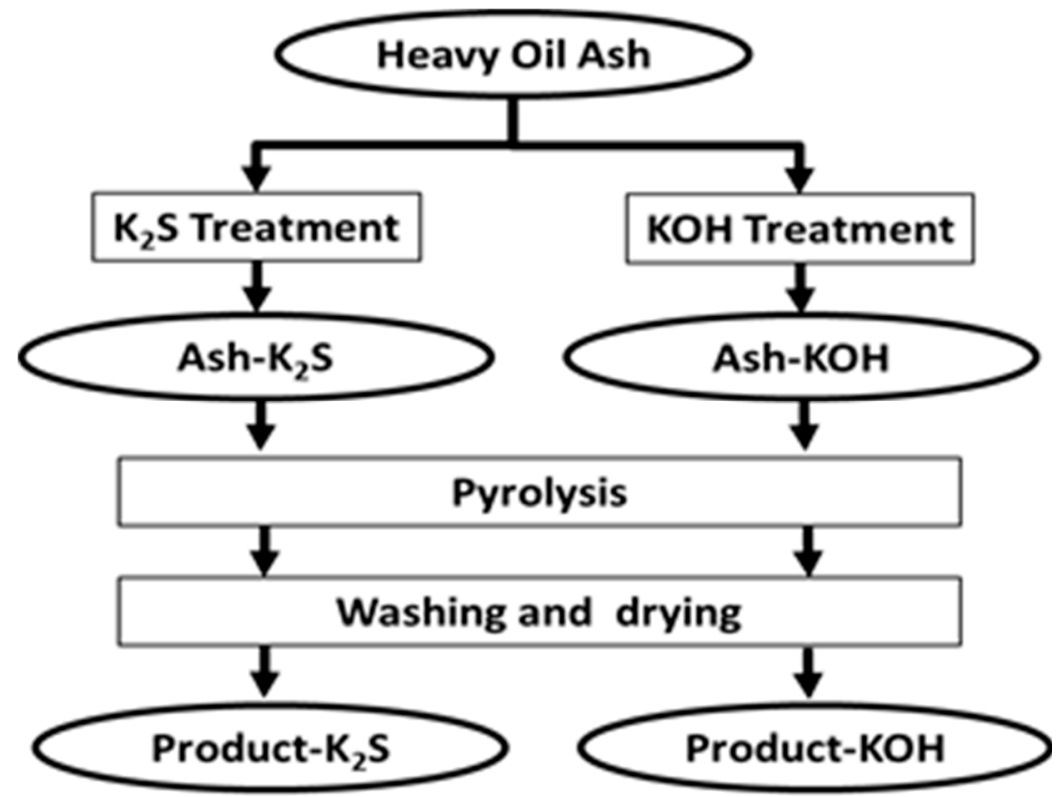

Figure 1. Flowchart for preparation of the product.

\subsection{Lead Removal}

$\mathrm{Pb}^{2+}$ adsorption capacities of the samples were examined using lead nitrate $\left(\mathrm{Pb}\left(\mathrm{NO}_{3}\right)_{2}\right)$ aqueous solutions. Each sample $(0.1 \mathrm{~g})$ was added to $10 \mathrm{mM} \mathrm{Pb}^{2+}$ solution $(10 \mathrm{~mL})$ in a centrifuge tube and shaken with a reciprocal shaker. After shaking for 1 day, the tube was centrifuged, and the $\mathrm{Pb}^{2+}$ concentration in the supernatant and the $\mathrm{pH}$ of the supernatant were measured.

The adsorption of $\mathrm{Pb}^{2+}$ by the S-impregnated adsorbents was examined using solutions containing various $\mathrm{Pb}^{2+}$ contents. Each adsorbent $(50 \mathrm{mg})$ was added to $0-8 \mathrm{mM} \mathrm{Pb}^{2+}$ solutions $(10 \mathrm{~mL})$ in tubes, which were shaken with a shaker. After shaking for 1 day, the tubes were centrifuged, and the $\mathrm{Pb}^{2+}$ concentrations in the supernatants and the $\mathrm{pH}$ values of the supernatants were measured.

The selectivity of $\mathrm{Pb}^{2+}$ removal of the S-impregnated adsorbents was examined using a mixed aqueous solution of $\mathrm{Pb}\left(\mathrm{NO}_{3}\right)_{2}$, zinc nitrate, and copper nitrate, each having a concentration of $1 \mathrm{mmol} / \mathrm{L}$ in the ternary solution. Each adsorbent $(0.1 \mathrm{~g})$ was added to $10 \mathrm{~mL}$ of ternary solutions having various $\mathrm{pH}$ values, which were adjusted to 1-4 using nitric acid solution, and the tubes were shaken with a shaker. After shaking for 1 day, the tubes were centrifuged, and the concentrations of $\mathrm{Pb}^{2+}, \mathrm{Zn}^{2+}$, and $\mathrm{Cu}^{2+}$ in the supernatants and the $\mathrm{pH}$ values of the supernatant were measured. 
The adsorption amounts $(q(\mathrm{mmol} / \mathrm{g}))$ and the removal ratio $(R(\%))$ were calculated using the following equations:

$$
\begin{gathered}
q_{M}=\left(C_{0}-C\right) \times V / w \\
R_{M}=\left(C_{0}-C\right) / C_{0} \times 100
\end{gathered}
$$

where $M=\mathrm{Pb}^{2+}, \mathrm{Zn}^{2+}$, or $\mathrm{Cu}^{2+} . C_{0}$ and $C$ are the initial and measured concentrations of $\mathrm{Pb}^{2+}, \mathrm{Zn}^{2+}$, and $\mathrm{Cu}^{2+}$ in the solution $(\mathrm{mmol} / \mathrm{L})$, respectively. $V$ is the solution volume $(\mathrm{L})$, and $w$ is the weight of the added sample (g).

\subsection{Characterization}

The chemical contents and mineralogical phases of the samples were analyzed via X-ray fluorescence (XRF-Primini, Rigaku, Tokyo, Japan) and powder X-ray diffraction (monochromated $\mathrm{CuK} \alpha$ radiation) (Ultima IV, Rigaku, Tokyo, Japan), respectively. The morphologies of the samples were observed via scanning electron microscopy (SU-70, Hitachi, Tokyo, Japan). The carbon contents in the samples were analyzed using a CHNS/O elemental analysis apparatus (2400II, Perkin Elmer Japan, Yokohama, Japan). The specific surface area of each sample was determined using an automatic gas adsorption apparatus (Belsorp-mini II, MicrotracBel, Osaka, Japan). The heavy metal ion concentrations in the solutions were analyzed using an inductively coupled plasma emission analyzer (SPS 5510, Hitachi, Tokyo, Japan). The $\mathrm{pH}$ of the solutions was measured by a $\mathrm{pH}$ meter (pH/Ion meter D-53, Horiba, Kyoto, Japan).

\section{Results and Discussion}

Figure 2 shows the mineral compositions of (a) raw ash, (b) Ash- $\mathrm{K}_{2} \mathrm{~S}$, and (c) Ash- $\mathrm{KOH}$. The raw ash mainly contains ammonium sulfate $\left(\left(\mathrm{NH}_{4}\right)_{2} \mathrm{SO}_{4}\right)$ and magnesium chloride $\left(\mathrm{MgCl}_{2}\right)$, produced by the neutralization of acidic gas by ammonia and magnesium oxide. After the treatment with $\mathrm{K}_{2} \mathrm{~S}$ and $\mathrm{KOH}$, these mineral phases are diminished, elemental $\mathrm{S}$ appears in Ash- $\mathrm{K}_{2} \mathrm{~S}$, and potassium sulfate $\left(\mathrm{K}_{2} \mathrm{SO}_{4}\right)$ appears in Ash-KOH.

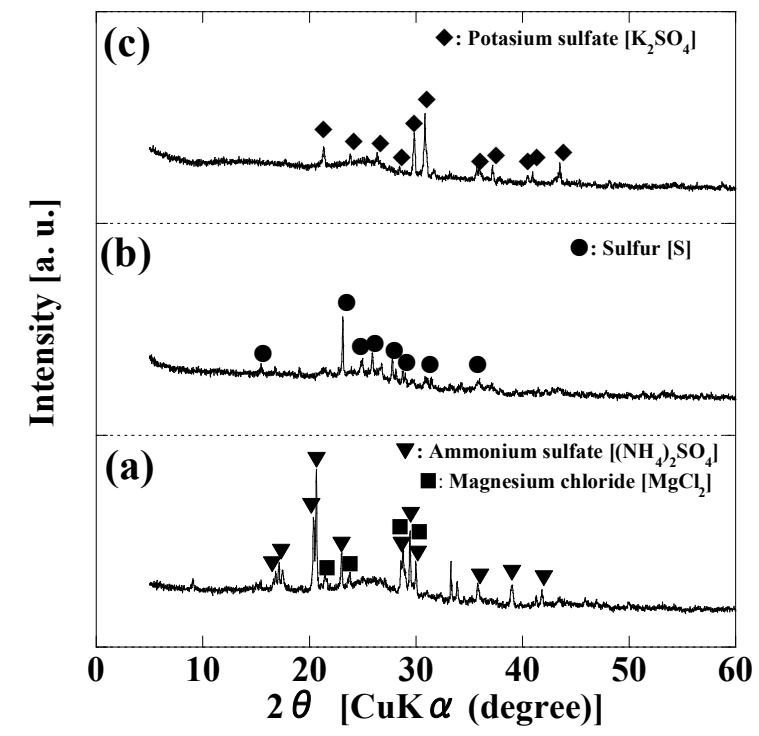

Figure 2. XRD patterns of (a) raw ash, (b) Ash- $\mathrm{K}_{2} \mathrm{~S}$, and (c) Ash-KOH.

Figure 3 shows the lead removal achieved by the products obtained at various pyrolysis temperatures. Regardless of the pyrolysis temperatures, the removal ability of Product- $\mathrm{K}_{2} \mathrm{~S}$ is higher than that of Product- $\mathrm{KOH}$. In the case of Product- $\mathrm{KOH}$, as the temperature of pyrolysis is increased to $600{ }^{\circ} \mathrm{C}$, the lead removal ability decreases to zero. The lead removal ability of the product obtained 
above $700{ }^{\circ} \mathrm{C}$ is higher than that of the product obtained at $600{ }^{\circ} \mathrm{C}$, and becomes almost constant (approximately $25 \%$ ). In the case of Product- $\mathrm{K}_{2} \mathrm{~S}$, as the temperature of pyrolysis increases to $300{ }^{\circ} \mathrm{C}$, the $\mathrm{Pb}^{2+}$ removal ability of the product increases, followed by a decrease up to $600{ }^{\circ} \mathrm{C}$, and becoming almost constant above $600{ }^{\circ} \mathrm{C}$. Therefore, the maximum lead removal ability achieved by heating Ash- $\mathrm{K}_{2} \mathrm{~S}$ is at $300{ }^{\circ} \mathrm{C}$.

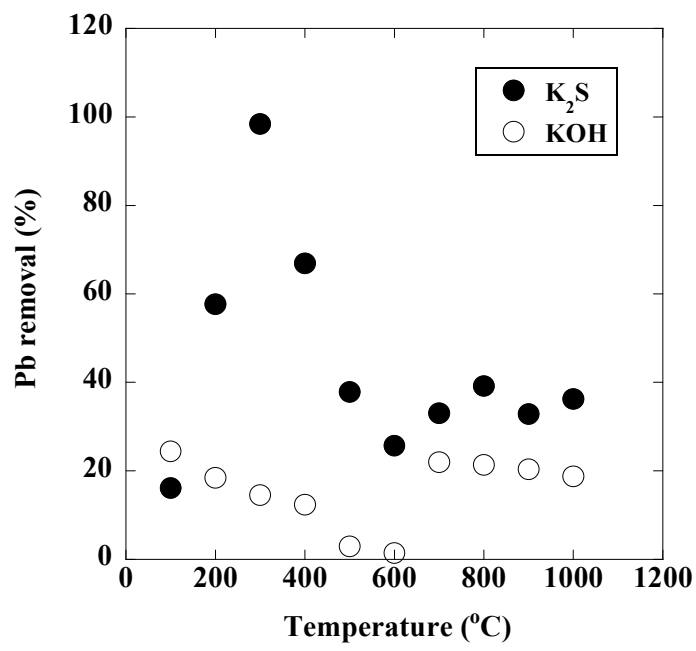

Figure 3. Lead removal abilities of Product- $\mathrm{K}_{2} \mathrm{~S}$ and Product-KOH.

Figure 4 shows the XRD patterns of (a) Product- $\mathrm{K}_{2} \mathrm{~S}$ and (b) Product- $\mathrm{KOH}$ after pyrolysis at various temperatures. All the obtained products present mainly amorphous phases produced by pyrolysis. It is noted that a metal alloy of Fe and $\mathrm{Ni}$ appears in Product- $\mathrm{K}_{2} \mathrm{~S}$ obtained at $1000{ }^{\circ} \mathrm{C}$ and in Product- $\mathrm{KOH}$ above $700{ }^{\circ} \mathrm{C}$, owing to the reduction of metal oxides in the ash by the carbon content.
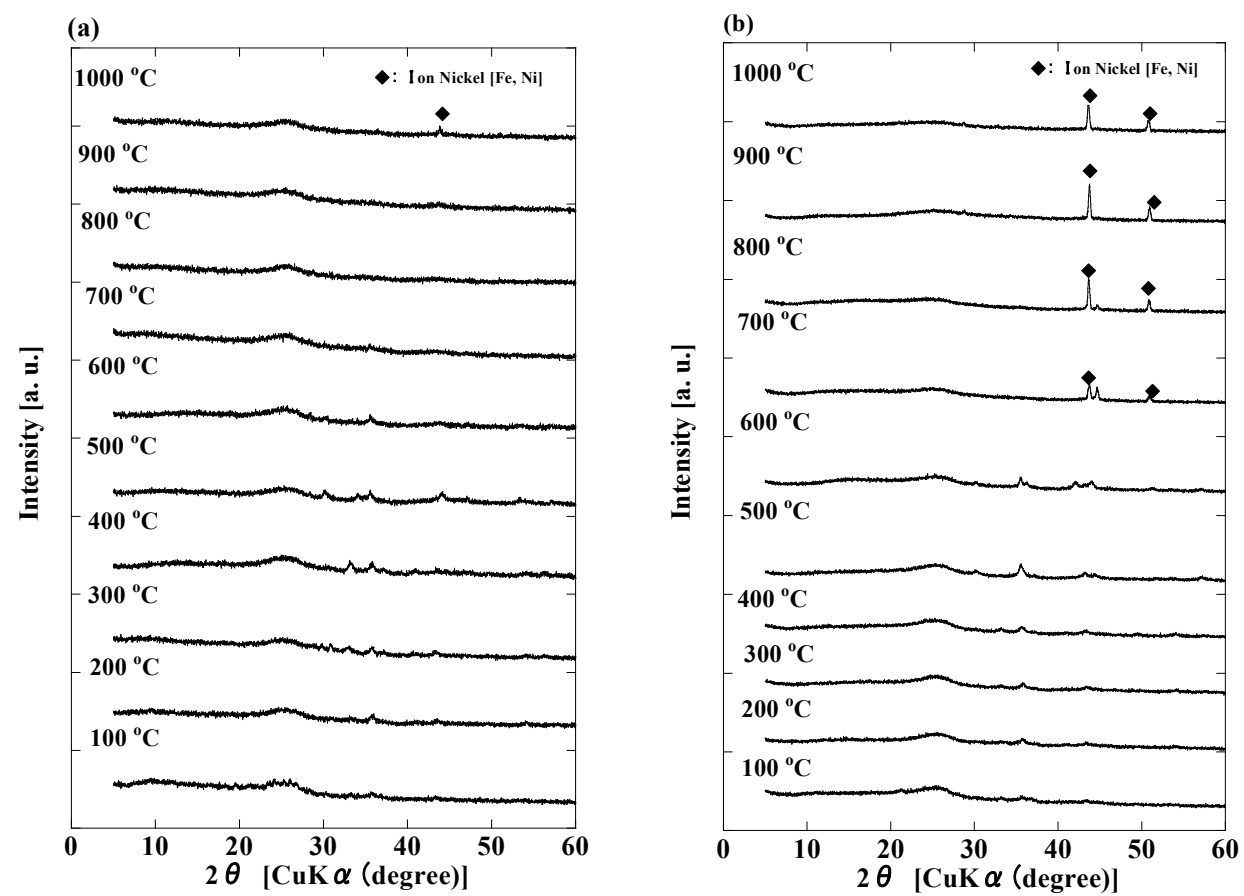

Figure 4. XRD patterns of (a) Product- $\mathrm{K}_{2} \mathrm{~S}$ and (b) Product-KOH after pyrolysis at various temperatures.

Figure 5 shows the contents of carbon and $\mathrm{S}$ of Ash- $\mathrm{K}_{2} \mathrm{~S}$, Ash- $\mathrm{KOH}$, Product- $\mathrm{K}_{2} \mathrm{~S}$, and Product- $\mathrm{KOH}$ as functions of the pyrolysis temperature. It is noted that the results of Ash- $\mathrm{K}_{2} \mathrm{~S}$ and Ash- $\mathrm{KOH}$ are 
plotted at the origin. The carbon contents of Ash- $\mathrm{K}_{2} \mathrm{~S}$ and Ash- $\mathrm{KOH}$ are approximately $50 \%$ each, which is lower than that of raw ash. After pyrolysis, the carbon contents of all the products are approximately $65-70 \%$. The S content of Ash- $\mathrm{K}_{2} \mathrm{~S}(12 \%)$ is higher than those of Ash-KOH (4\%) and raw ash (4\%). After pyrolysis, the $\mathrm{S}$ contents of all the Product- $\mathrm{K}_{2} \mathrm{~S}$ are higher than those of all the Product-KOH. The $\mathrm{S}$ content of Product- $\mathrm{K}_{2} \mathrm{~S}$ obtained at $100{ }^{\circ} \mathrm{C}$ is almost the same as that of Ash- $\mathrm{K}_{2} \mathrm{~S}$, and that of Product- $\mathrm{K}_{2} \mathrm{~S}$ obtained above $200{ }^{\circ} \mathrm{C}$ is almost constant (5-7.5\%), which are lower than those of Ash- $\mathrm{K}_{2} \mathrm{~S}$. The $\mathrm{S}$ content of Product- $\mathrm{KOH}$ is almost constant, which is almost same as that of Ash-KOH.

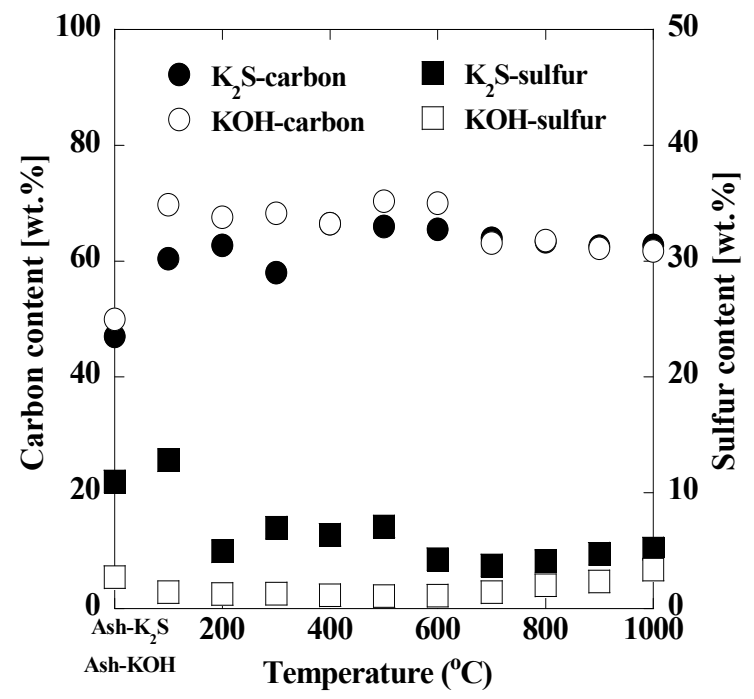

Figure 5. Contents of carbon and sulfur of products pyrolyzed at various pyrolysis temperatures.

Figure 6 shows the specific surface areas of Ash- $\mathrm{K}_{2} \mathrm{~S}$, Ash- $\mathrm{KOH}$, Product- $\mathrm{K}_{2} \mathrm{~S}$, and Product- $\mathrm{KOH}$ as functions of the pyrolysis temperature. It is also noted that the results of $A s h-K_{2} S$ and $A s h-K O H$ are plotted at the origin. The specific surface areas of raw ash, Ash- $\mathrm{K}_{2} \mathrm{~S}$, and Ash-KOH are almost the same (approximately 6\%). After pyrolysis, regardless of the pyrolysis temperature, the specific surface area of Product- $\mathrm{K}_{2} \mathrm{~S}$ is lower than that of Product- $\mathrm{KOH}$, and both are almost constant $(5-10 \%$ and $15-20 \%$, respectively).

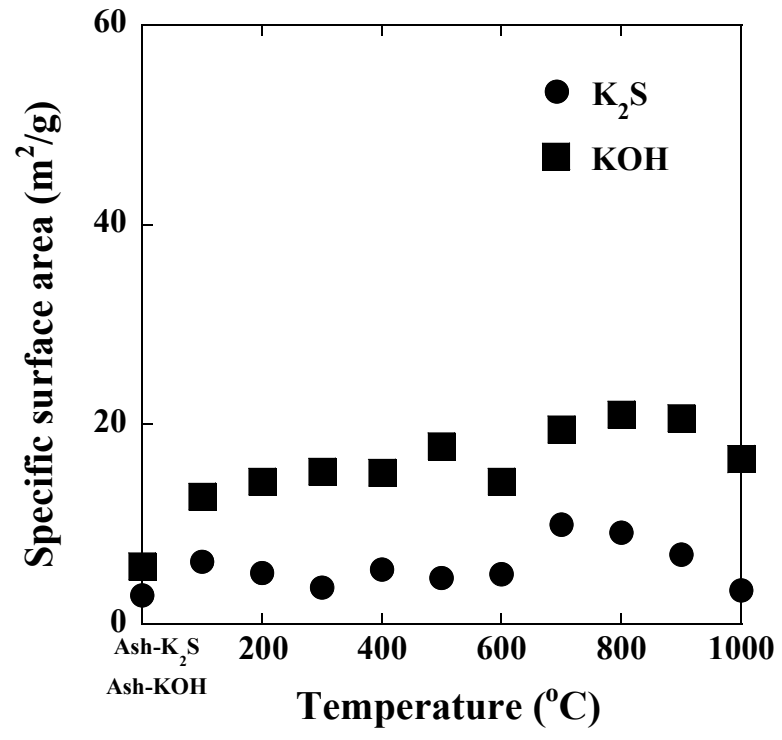

Figure 6. Specific surface areas of products pyrolyzed at various temperatures. 
The $\mathrm{S}$ contents of Ash- $\mathrm{K}_{2} \mathrm{~S}$ and Ash- $\mathrm{KOH}$ comprise elemental $\mathrm{S}$ and $\mathrm{K}_{2} \mathrm{SO}_{4}$, respectively. Volatile matters in these ashes are released at $100-200{ }^{\circ} \mathrm{C}$ to form carbonaceous materials. The melting and boiling points of elemental $\mathrm{S}$ are $188^{\circ} \mathrm{C}$ and $445^{\circ} \mathrm{C}$, respectively, whereas those of potassium sulfate are $1069^{\circ} \mathrm{C}$ and $1689^{\circ} \mathrm{C}$, respectively. For Ash- $\mathrm{K}_{2} \mathrm{~S}$, melting $\mathrm{S}$ was rated with the surface of carbonaceous ash to form $\mathrm{S}$ functional groups for heavy metal ion removal at $200-400{ }^{\circ} \mathrm{C}$. Moreover, $\mathrm{S}$ was vaporized without reacting with the carbonaceous surface above $400{ }^{\circ} \mathrm{C}$. Therefore, the lead removal ability of the product pyrolyzed at approximately $300{ }^{\circ} \mathrm{C}$ from Ash- $\mathrm{K}_{2} \mathrm{~S}$ is the highest. For Ash- $\mathrm{KOH}, \mathrm{K}_{2} \mathrm{SO}_{4}$ does not react with the carbonaceous surface without the melting $\mathrm{S}$ content forming the $S$ functional group. Therefore, the lead removal ability of the product pyrolyzed from Ash-KOH is lower than of that from Ash- $\mathrm{K}_{2} \mathrm{~S}$.

The SEM images of (a) the raw ash, (b) Product- $\mathrm{K}_{2} \mathrm{~S}$ obtained at $300{ }^{\circ} \mathrm{C}$, and (c) Product- $\mathrm{KOH}$ at $300{ }^{\circ} \mathrm{C}$ are shown in Figure 7. A collection of spongy particles and some aggregates are observed in the raw ash, and the morphologies of both the obtained products appear very similar to that of the starting ash, which suggests that the spongy structure of the heavy oil ash is maintained in the obtained adsorbents.
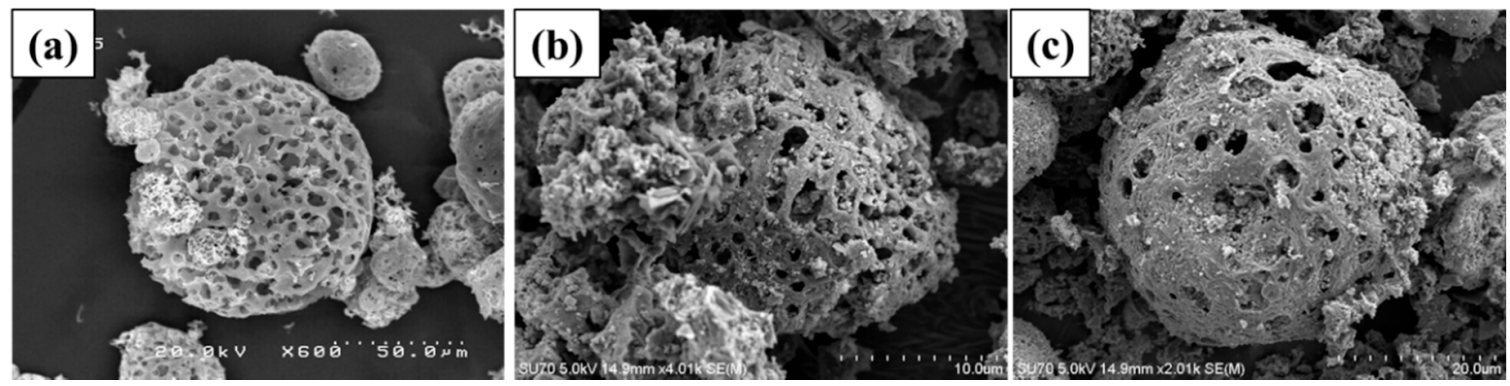

Figure 7. SEM photographs of (a) raw ash, (b) Product- $\mathrm{K}_{2} \mathrm{~S}$ obtained at $300{ }^{\circ} \mathrm{C}$, and (c) Product-KOH at $300^{\circ} \mathrm{C}$.

The lead removal isotherm of Product- $\mathrm{K}_{2} \mathrm{~S}$ obtained at $300^{\circ} \mathrm{C}$ is shown in Figure 8 . With the increase in the equilibrium lead concentration, the lead adsorption increases to approximately $0.4 \mathrm{mmol} / \mathrm{g}$, and then becomes almost constant. The isotherm was analyzed using two typical isotherm models: Langmuir and Freundlich models. The liner forms of the Langmuir and Freundlich models are given by:

$$
\begin{gathered}
C_{e} / q_{e}=1 /\left(Q_{\max } \times K_{L}\right)+C_{e} / Q_{\max } \\
\ln \left(q_{e}\right)=\ln \left(K_{F}\right)+(1 / n) \times \ln \left(C_{e}\right)
\end{gathered}
$$

where $q_{e}$ is the lead concentration on the adsorbent at equilibrium (mmol/g), and $Q_{\max }(\mathrm{mmol} / \mathrm{g})$ and $K_{L}(\mathrm{~L} / \mathrm{mmol})$ are the maximum adsorption capacity and Langmuir constant (equilibrium adsorption constant), respectively. $K_{F}$ and $n$ are the Freundlich constants.

The calculated parameters for each isotherm model are listed in Table 2. The correlation regression coefficient $\left(R^{2}\right)$ as a measure of the goodness-of-fit using the Langmuir and Freundlich models are 0.999 and 0.813 , respectively, indicating that the Langmuir model is fitted better than the Freundlich model. This suggests that the lead adsorption occurs uniformly and follows monolayer adsorption, instead of multilayer adsorption. Moreover, the adsorption occurs at equivalent adsorption energies and homogeneous binding sites with no interaction between the adsorbates [16]. The calculated maximum adsorption capacity, $Q_{\max }$, is $0.38 \mathrm{mmol} / \mathrm{g}$. The lead adsorbents, such as natural materials [17-19], synthetic carbon materials [20-22], and activated carbon prepared from wastes [23-30] were reported, and the maximum adsorption capacity of $0.38 \mathrm{mmol} / \mathrm{g}$ is comparable to those of other reported adsorbents (Table 3). It can be concluded that the adsorbent obtained from oil ash by S-impregnation is a promising material for treatment of wastewater containing lead ion. 


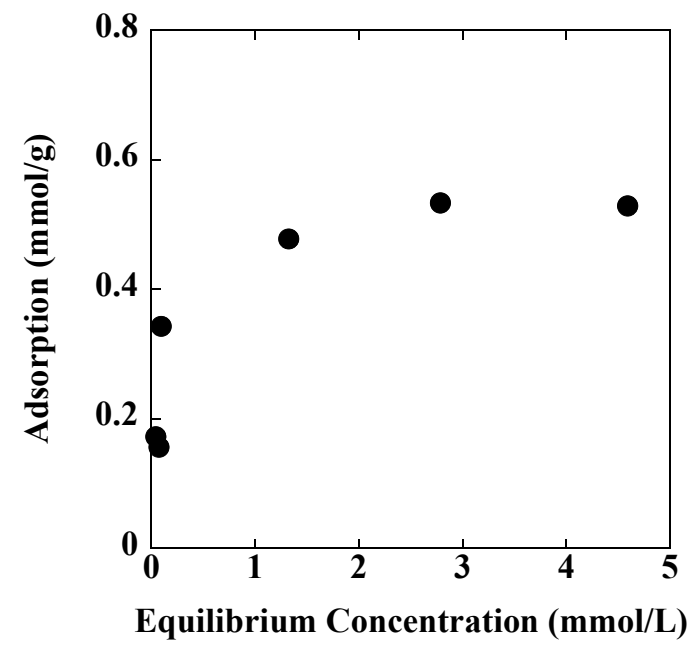

Figure 8. Isotherm of lead ion using Product- $\mathrm{K}_{2} \mathrm{~S}$ obtained at $300{ }^{\circ} \mathrm{C}$.

Table 2. Parameters and correlation regression for two models, Langmuir and Freundlich.

\begin{tabular}{cccccc}
\hline \multicolumn{3}{c}{ Langmuir } & \multicolumn{3}{c}{ Freundlich } \\
\hline$Q_{\max }$ & $K_{L}$ & $R^{2}$ & $N$ & $K_{F}$ & $R^{2}$ \\
\hline 0.54 & 8.48 & 0.999 & 4.06 & 0.41 & 0.813 \\
\hline
\end{tabular}

Table 3. Comparison of lead ion adsorption with some reported data.

\begin{tabular}{ccc}
\hline Adsorbent & Adsorption Capacity $\mathbf{( m m o l} / \mathbf{g})$ & Reference \\
\hline Siderite & 0.06 & {$[17]$} \\
Kaolinite clay & 0.09 & {$[18]$} \\
Rice husk ash & 0.06 & {$[19]$} \\
Carbon nanotube & 0.14 & {$[20]$} \\
Alumina supported iron oxide & 0.01 & {$[21]$} \\
Sulfur-functionalized ordered mesoporous carbon & 0.14 & {$[22]$} \\
Hazelnut husk activated carbon & 0.06 & {$[23]$} \\
Date pits activated carbon & 0.15 & {$[24]$} \\
Peanut hull activated carbon & 0.15 & {$[25]$} \\
Rice straw activated carbon & 0.17 & {$[26]$} \\
Algal waste activated carbon & 0.21 & {$[27]$} \\
Pecan shell activated carbon & 0.31 & {$[28]$} \\
Coconut shell activated carbon & 0.37 & {$[29]$} \\
Palm shell activated carbon & 0.4 & {$[30]$} \\
\hline
\end{tabular}

Lead removal ability of Product- $\mathrm{K}_{2} \mathrm{~S}$ prepared at $300{ }^{\circ} \mathrm{C}$ from ternary solutions was examined. Figure 9 presents the heavy metal removal ability of the product from a $\mathrm{Pb}^{2+}-\mathrm{Zn}^{2+}-\mathrm{Cu}^{2+}$ solution. The product can remove $\mathrm{Pb}^{2+}$ and $\mathrm{Cu}^{2+}$ ions from the ternary solution, whereas $\mathrm{Zn}^{2+}$ ions cannot be removed in this experiment. With the increase in the equilibrium $\mathrm{pH}$, the removal of $\mathrm{Pb}^{2+}$ first increases from $\mathrm{pH} 3$ to $\mathrm{pH} 6$, and then that of $\mathrm{Cu}^{2+}$ increases from $\mathrm{pH} 4.5$ to $\mathrm{pH}$. The increase in the removal of $\mathrm{Pb}^{2+}$ and $\mathrm{Cu}^{2+}$ when the $\mathrm{pH}$ increases may be attributed to two reasons. First, the number of negatively charged active sites increases and the number of positively charged sites decreases at high $\mathrm{pH}$ values, which increase the electrostatic adsorption between the metal ions and the S-impregnated product. Second, at a low $\mathrm{pH}$, the competitive interaction between the metal ions and protons with the active sites increases, resulting in a low adsorption capacity of the metal ions.

The order of adsorption using Product- $\mathrm{K}_{2} \mathrm{~S}-300$ is $\mathrm{Pb}^{2+}>\mathrm{Cu}^{2+}>\mathrm{Zn}^{2+}$, indicating that the product has a high affinity for $\mathrm{Pb}^{2+}$ among the heavy metal ions. A functionalized carbon nanotube with $\mathrm{S}$ functional groups $(=\mathrm{C}=\mathrm{S},-\mathrm{SH})$ presented increased adsorption of $\mathrm{Cu}^{2+}$ with an increase of the solution 
$\mathrm{pH}$ from 2 to 6 and was more favorable to $\mathrm{Cu}^{2+}$ than $\mathrm{Zn}^{2+}$ [31]. For a resin with sulfur functional groups, the adsorption of $\mathrm{Pb}^{2+}$ and $\mathrm{Cu}^{2+}$ increases with an increase of the solution $\mathrm{pH}$, and the adsorption amount of $\mathrm{Pb}^{2+}$ is slightly higher than that of $\mathrm{Cu}^{2+}$ [32]. There is good agreement with our results.

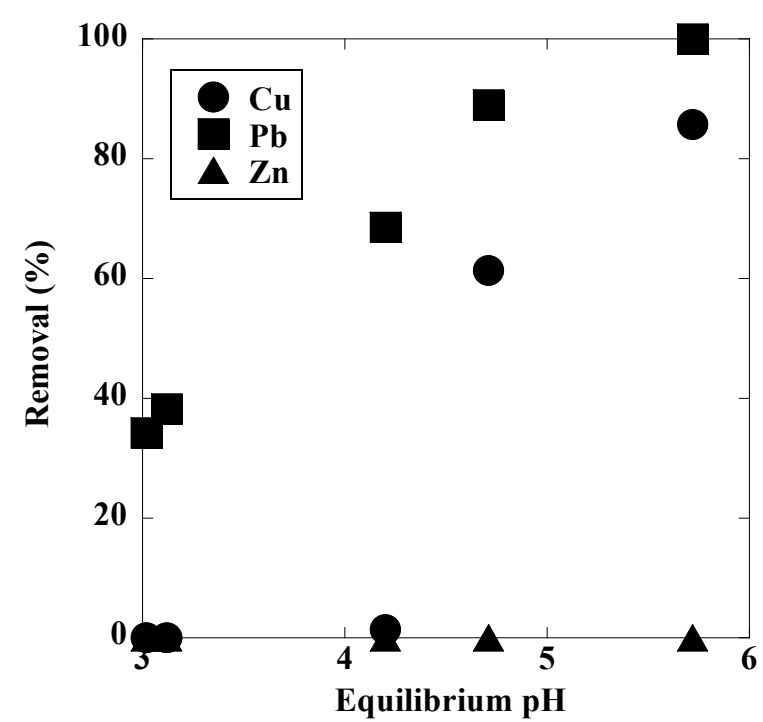

Figure 9. Removal of Product- $\mathrm{K}_{2} \mathrm{~S}$ obtained at $300{ }^{\circ} \mathrm{C}_{\text {for }} \mathrm{Pb}^{2+}, \mathrm{Zn}^{2+}$, and $\mathrm{Cu}^{2+}$ from the mixed solution.

From these results, a carbonaceous product can be prepared by both the procedures, and Product- $\mathrm{K}_{2} \mathrm{~S}$ has a higher lead removal ability than Product- $\mathrm{KOH}$. Product- $\mathrm{K}_{2} \mathrm{~S}$ has a higher $\mathrm{S}$ content and lower specific surface area than Product- $\mathrm{KOH}$, which suggests that chemical adsorption with $\mathrm{S}$ content has a higher dependence on lead removal from an aqueous solution than physical adsorption.

\section{Conclusions}

Preparation of a carbonaceous adsorbent with removal of heavy metals from heavy oil ash by $S$ impregnation was investigated, and its lead removal ability from an aqueous solution was estimated. $\mathrm{K}_{2} \mathrm{~S}$ solution can immerse $\mathrm{S}$ into the ash, and $\mathrm{K}_{2} \mathrm{~S}$-immersed ash can be converted into a carbonaceous product with a high $\mathrm{S}$ content by pyrolysis. Product- $\mathrm{K}_{2} \mathrm{~S}$ pyrolyzed at $300{ }^{\circ} \mathrm{C}$ presents the highest lead adsorption from an aqueous solution, and there is high selective removal for lead ions from a ternary $\mathrm{Pb}^{2+}-\mathrm{Cu}^{2+}-\mathrm{Zn}^{2+}$ solution. The lead removal is found to fit the Langmuir adsorption model more than the Freundlich model. In the ternary $\mathrm{Pb}^{2+}-\mathrm{Cu}^{2+}-\mathrm{Zn}^{2+}$ solution, with an increase in the solution $\mathrm{pH}$, the removal of $\mathrm{Pb}^{2+}$ and $\mathrm{Cu}^{2+}$ increased and the order of adsorption was $\mathrm{Pb}^{2+}>\mathrm{Cu}^{2+}>\mathrm{Zn}^{2+}$. The carbonaceous adsorbent with heavy metal removal can be prepared from heavy oil ash by $\mathrm{S}$ impregnation, and it can be applied to water treatment for heavy metal removal, particularly $\mathrm{Pb}^{2+}$.

Funding: This research was partly supported by the Environmental Research and Technology Development Fund (K113029) of the Ministry of the Environment, Japan, JSPS KAKENHI (20K12234): Grant-in-Aid for Scientific Research (C), and by the Arai Science and Technology Foundation.

Conflicts of Interest: The authors declare no conflict of interest.

\section{References}

1. Amer, A.M. Processing of Egyptian boiler-ash for extraction of vanadium and nickel. Waste Manag. 2002, 22, 515-520. [CrossRef]

2. Tsai, S.-L.; Tsai, M.-S. A study of the extraction of vanadium and nickel in oil-fired fly ash. Resour. Conserv. Recycl. 1998, 22, 163-176. [CrossRef]

3. Hsieh, Y.-M.; Tsai, M.-S. Physical and chemical analyses of unburned carbon from oil-fired fly ash. Carbon 2003, 41, 2317-2324. [CrossRef] 
4. Caramuscio, P.; De Stefano, L.; Seggiani, M.; Vitolo, S.; Narducci, P. Preparation of activated carbons from heavy-oil ash. Waste Manag. 2003, 23, 345-351. [CrossRef]

5. Seggiani, M.; Vitolo, S.; Narducci, P. Investigation on the porosity development by $\mathrm{CO}_{2}$ activation in heavy oil ashes. Fuel 2003, 82, 1441-1450. [CrossRef]

6. Seggiani, M.; Vitolo, S.; Filippis, P.D. Effect of pre-oxidation on the porosity development in a heavy oil fly ash by $\mathrm{CO}_{2}$ activation. Fuel 2005, 84, 1593-1596. [CrossRef]

7. Adhoum, N.; Monser, L. Removal of cyanide from aqueous solution using impregnated activated carbon. Chem. Eng. Process. 2002, 41, 17-21. [CrossRef]

8. Sadraei, R.; Paganini, M.C.; Calza, P.; Magnacca, G. An easy synthesis for preparing bia-based hybrid adsorbent useful for fast adsorption of polar pollutants. Nanomaterials 2019, 9, 731. [CrossRef]

9. Magnacca, G.; Santos, F.N.D.; Sadraei, R. Bio-based substances from compost as reactant and active phase for selective capture of cationic pollutants from waste water. Front. Chem. 2020, 8, 550. [CrossRef]

10. Volkan, M.; Ataman, A.; Howard, A. Pre-concentration of some trace metals from sea water on a mercapto-modified silica gel. Analyst 1987, 112, 1409-1412. [CrossRef]

11. Krishnan, K.A.; Anirudhan, T.S. Removal of cadmium(II) from aqueous solutions by steam-activated sulphurised carbon prepared from sugar-cane bagasse pith: Kinetics and equilibrium studies. Water $S A$ 2003, 29, 147-156. [CrossRef]

12. Gomez-Serrano, V.; Macias-Garcia, A.; Espinosa-Mansilla, A.; Valenzuela-Calahorroc, C. Adsorption of mercury, cadmium and lead from aqueous solution on heat-treated and sulphurized activated carbon. Water Res. 1998, 32, 1-4. [CrossRef]

13. Wajima, T. A new carbonaceous adsorbent for heavy metal removal from aqueous solution prepared from paper sludge by sulfur-impregnation and pyrolysis. Process Saf. Environ. Prot. 2017, 112, 342-352. [CrossRef]

14. Pearson, R.G. Hard and soft acids and bases. J. Am. Chem. Soc. 1963, 85, 3533-3539. [CrossRef]

15. Pearson, R.G. Recent advances in the concept of hard and soft acids and bases. J. Chem. Educ. 1987, 64, 561-567. [CrossRef]

16. Zhao, D.; Gao, X.; Wu, C.; Xie, R.; Feng, S.; Chen, C. Facile preparation of amino functionalized graphene oxide decorated with $\mathrm{Fe}_{2} \mathrm{O}_{3}$ nanoparticles for the adsorption of $\mathrm{Cr}$ (IV). Appl. Surf. Sci. 2016, 384, 1-9. [CrossRef]

17. Erdem, M.; Ozverdi, A. Lead adsorption from aqueous solution onto siderite. Sep. Purif. Technol. 2005, 42, 259-264. [CrossRef]

18. Adebowale, K.O.; Unuabonah, I.E.; Olu-Owolabi, B.I. The effect of some operating variables on the adsorption of lead and cadmium ions on kaolinite clay. J. Hazard. Mater. 2006, 134, 130-139. [CrossRef]

19. Feng, Q.; Lin, Q.; Gong, F.; Sugita, S.; Shoya, M. Adsorption of lead and mercury by rice husk ash. J. Colloid Interface Sci. 2004, 278, 1-8. [CrossRef]

20. Huang, Y.H.; Hsueh, C.L.; Huang, C.P.; Su, L.C.; Chen, C.Y. Adsorption thermodynamic and kinetic studies of $\mathrm{Pb}$ (II) removal from water onto a versatile $\mathrm{Al}_{2} \mathrm{O}_{3}$-supported iron oxide. Sep. Purif. Technol. 2007, 55, 23-29. [CrossRef]

21. Vuković, G.D.; Marinković, A.D.; Škapin, S.D.; Ristić, M.T.; Aleksić, R.; Perić-Grujić, A.A.; Uskoković, P.S. Removal of lead from water by amino modified multi-walled carbon nanotubes. Chem. Eng. J. 2011, 173, 855-865. [CrossRef]

22. Saha, D.; Barakat, S.; Bramer, S.E.V.; Nelson, K.A.; Hensley, D.K.; Chen, J. Noncompetitive and competitive adsorption of heavy metals in sulfur-functionalized ordered mesoporous carbon. ACS Appl. Mater. Interfaces 2016, 8, 34132-34142. [CrossRef] [PubMed]

23. Imamoglu, M.; Tekir, O. Removal of copper (II) and lead (II) ions from aqueous solutions by adsorption on activated carbon from a new precursor hazelnut husks. Desalination 2008, 228, 108-113. [CrossRef]

24. Abdulkarim, M.; Al-Rub, F.A. Adsorption of lead ions from aqueous solution onto activated carbon and chemically-modified activated carbon prepared from date pits. Adsorp. Sci. Technol. 2004, 22, 119-134. [CrossRef]

25. Brown, P.; Jefcoat, I.A.; Parrish, D.; Gil, S.; Graham, E. Evaluation of the adsorptive capacity of peanut hull pellets for heavy metals in solution. Adv. Environ. Res. 2000, 4, 19-29. [CrossRef]

26. Johns, M.M.; Marshall, W.E.; Toles, C.A. Agricultural by-products as granular activated carbons for adsorbing dissolved metals and organics. J. Chem. Technol. Biotechnol. 1998, 71, 131-140. [CrossRef]

27. Vilar, V.J.P.; Botelho, C.M.S.; Boaventura, R.A.R. Influence of $\mathrm{pH}$, ionic strength and temperature on lead biosorption by Gelidium and agar extraction algal waste. Process Biochem. 2005, 40, 3267-3275. [CrossRef] 
28. Bansode, R.R.; Losso, J.N.; Marshall, W.E.; Rao, R.M.; Portier, R.J. Adsorption of metal ions by pecan shell-based granular activated carbons. Bioresour. Technol. 2003, 89, 115-119. [CrossRef]

29. Kikuchi, Y.; Qian, Q.; Machida, M.; Tatsumoto, H. Effect of ZnO loading to activated carbon on Pb (II) adsorption from aqueous solution. Carbon 2006, 44, 195-202. [CrossRef]

30. Issabayeva, G.; Aroua, M.K.; Sulaiman, N.M.N. Removal of lead from aqueous solutions on palm shell activated carbon. Bioresour. Technol. 2006, 97, 2350-2355. [CrossRef]

31. Li, Q.; Yu, J.; Zhou, F.; Jiang, X. Synthesis and characterization of dithiocarbamate carbon nanotubes for the removal of heavy metal ions from aqueous solutions. Colloids Surf. A 2015, 482, 306-314. [CrossRef]

32. Jing, X.; Liu, F.; Yang, X.; Ling, P.; Li, L.; Long, C.; Li, A. Adsorption performances and mechanisms of the newly synthesized $\mathrm{N}, \mathrm{N}^{\prime}$-di(carboxymethyl) dithiocabamate chelating resin toward divalent heavy metal ions from aqueous media. J. Hazard. Mater. 2009, 167, 589-596. [CrossRef] [PubMed]

Publisher's Note: MDPI stays neutral with regard to jurisdictional claims in published maps and institutional affiliations.

(C) 2020 by the author. Licensee MDPI, Basel, Switzerland. This article is an open access article distributed under the terms and conditions of the Creative Commons Attribution (CC BY) license (http://creativecommons.org/licenses/by/4.0/). 